\title{
In vitro inhibition of breast cancer spheroid-induced lymphendothelial defects resembling intravasation into the lymphatic vasculature by acetohexamide, isoxsuprine, nifedipin and proadifen
}

N Kretschy ${ }^{1,8}$, M Teichmann ${ }^{1,8}$, S Kopf ${ }^{1}$, A G Atanasov ${ }^{2}$, P Saiko ${ }^{3}$, C Vonach ${ }^{1}$, K Viola ${ }^{1}$, B Giessrigl ${ }^{1}$, N Huttary ${ }^{1}$, I Raab ${ }^{1}$, S Krieger ${ }^{1}$, W Jäger ${ }^{4}$, T Szekeres ${ }^{3}$, S M Nijman ${ }^{5}$, W Mikulits ${ }^{6}$, V M Dirsch ${ }^{2}$, H Dolznig ${ }^{7}$, M Grusch $^{6}$ and G Krupitza*,1

${ }^{1}$ Institute of Clinical Pathology, Medical University of Vienna, Waehringer Guertel 18-20, A-1090 Vienna, Austria; ${ }^{2}$ Department of Pharmacognosy, University of Vienna, Althanstrasse 14, A-1090 Vienna, Austria; ${ }^{3}$ Clinical Institute of Medical and Chemical Laboratory Diagnostics, Medical University of Vienna, Waehringer Guertel 18-20, A-1090 Vienna, Austria; ${ }^{4}$ Department for Clinical Pharmacy and Diagnostics, Faculty of Life Sciences, University of Vienna, Althanstrasse 14, A-1090 Vienna, Austria; ${ }^{5}$ Research Center for Molecular Medicine of the Austrian Academy of Sciences, Lazarettgasse 14, AKH BT 25.3, A-1090 Vienna, Austria; ${ }^{6}$ Department of Medicine I, Institute of Cancer Research, Medical University of Vienna, Borschkegasse 8a, A-1090 Vienna, Austria and ${ }^{7}$ Institute of Medical Genetics, Medical University of Vienna, Waehringer Strasse 10, A-1090 Vienna, Austria

Background: As metastasis is the prime cause of death from malignancies, there is vibrant interest to discover options for the management of the different mechanistic steps of tumour spreading. Some approved pharmaceuticals exhibit activities against diseases they have not been developed for. In order to discover such activities that might attenuate lymph node metastasis, we investigated 225 drugs, which are approved by the US Food and Drug Administration.

Methods: A three-dimensional cell co-culture assay was utilised measuring tumour cell-induced disintegrations of the lymphendothelial wall through which tumour emboli can intravasate as a limiting step in lymph node metastasis of ductal breast cancer. The disintegrated areas in the lymphendothelial cell (LEC) monolayers were induced by 12(S)-HETE, which is secreted by MCF-7 tumour cell spheroids, and are called 'circular chemorepellent induced defects' (CCIDs). The putative mechanisms by which active drugs prevented the formation of entry gates were investigated by western blotting, NF- $\kappa \mathrm{B}$ activity assay and by the determination of 12(S)-HETE synthesis.

Results: Acetohexamide, nifedipin, isoxsuprine and proadifen dose dependently inhibited the formation of CCIDs in LEC monolayers and inhibited markers of epithelial-to-mesenchymal-transition and migration. The migration of LECs is a prerequisite of CCID formation, and these drugs either repressed paxillin levels or the activities of myosin light chain 2, or myosin-binding subunit of myosin phosphatase. Isoxsuprine inhibited all three migration markers, and isoxsuprine and acetohexamide suppressed

\footnotetext{
*Correspondence: Dr G Krupitza; E-mail: georg.krupitza@meduniwien.ac.at
}

${ }^{8}$ These authors contributed equally to this paper.

Revised 27 November 2012; accepted 28 November 2012; published online 8 January 2013

(C) 2013 Cancer Research UK. All rights reserved 0007 - 0920/13 
the synthesis of 12(S)-HETE, whereas proadifen and nifedipin inhibited NF- $\kappa$ B activation. Both the signalling pathways independently cause CCID formation.

Conclusion: The targeting of different mechanisms was most likely the reason for synergistic effects of different drug combinations on the inhibition of CCID formation. Furthermore, the treatment with drug combinations allowed also a several-fold reduction in drug concentrations. These results encourage further screening of approved drugs and their in vivo testing.

\section{INTRODUCTION}

Lipoxygenases were shown to have a significant role in tumour metastasis. MCF-7 breast cancer cells secrete 12(S)-HETE (Uchide et al, 2007), a metabolite of lipoxygenases 12 and 15-1 (ALOX12 or ALOX15-1), which repels different types of endothelial cells (Honn et al, 1994; Madlener et al, 2010). When placing MCF-7 cell spheroids on lymphendothelial cell (LEC) monolayers, the secreted 12(S)-HETE causes the retraction of underneath growing LECs, giving way to cell-free zones called 'circular chemorepellent induced defects' (CCIDs). The CCIDs are formed by the directional migration of LECs, and this phenomenon faithfully resembles bulky tumour intravasation through the lymphatic cell wall. Therefore, CCIDs, which are caused by 12(S)-HETE, are considered as entry gates for intravasating tumour emboli (Kerjaschki et al, 2011). 12(S)-HETE production correlates with lymph node metastasis of ductal breast cancer in human patients and inhibiting 12(S)-HETE synthesis by experimental drugs (i.e., the ALOX12/15 inhibitors baicalein or NDGA) and genetic manipulations (knock down of ALOX15) reduce the size of CCIDs and the metastatic spread into lymph nodes in a breast cancer xenograft mouse model (Kerjaschki et al, 2011). NDGA and baicalein are preclinical drugs which have no approval for clinical use. Hence, we screened 225 drugs, which are approved by the US Food and Drug Administration (FDA), regarding their CCIDinhibitory properties to evaluate their potential in anti-metastatic therapy.

\section{MATERIALS AND METHODS}

Reagents and antibodies. The NF- $\kappa \mathrm{B}$ inhibitor parthenolide, the I- $\kappa \mathrm{B} \alpha$ phosphorylation inhibitor (E)-3-(4-methylphenylsulfonyl)2-propenenitrile (Bay11-7082) and the ALOX12/15 inhibitor baicalein (EI-106) were purchased from Biomol (Hamburg, Germany), and 12(S)-HETE was purchased from Cayman Chemical (Ann Arbor, MI, USA). Acetohexamide (no. A178), dimethyl sulfoxide (DMSO, minimum 99.5\% GC, no. D4540), isoxsuprine hydrochloride (no. I0880), nifedipin (no. N7634) and proadifen hydrochloride (no. P1061) were purchased from SigmaAldrich (Munich, Germany). Mouse monoclonal anti-CD54 (ICAM-1) antibody was from Immunotech (Marseille, France), and polyclonal rabbit anti-paxillin (H-114) (sc-5574) and $\beta$-tubulin (H-235, sc-9104) were from Santa Cruz Biotechnology (Heidelberg, Germany). Monoclonal mouse anti-phospho-p44/42 MAPK (Erk1/2) (Thr202/Tyr204) (E10), monoclonal rabbit antip44/42 MAPK (Erk1/2) (137F5), polyclonal rabbit anti-phosphomyosin light chain 2 (MLC2) (Ser19), polyclonal rabbit anti-MLC2 and polyclonal rabbit anti-myosin-binding subunit of myosin phosphatase (MYPT1) were from Cell Signaling (Danvers, MA, USA). Monoclonal mouse anti- $\beta$-actin (clone AC-15) was from Sigma-Aldrich, polyclonal rabbit anti-phospho-MYPT1 (Thr696) was from Upstate (Lake Placid, NY, USA), and monoclonal mouse anti-CD31 (JC70A), polyclonal rabbit anti-mouse and anti-rabbit IgGs were from Dako (Glostrup, Denmark).

Cell culture. Human MCF-7 breast cancer cells were purchased from the American Type Culture Collection (Rockville, MD, USA) and grown in MEM medium supplemented with $10 \%$ fetal calf serum (FCS) and 1\% penicillin/streptomycin (PS) (Invitrogen, Karlsruhe, Germany). Telomerase-immortalised human LECs were grown in EGM2 MV (CC-4147; Clonetics, Allendale, NJ, USA), all at $37^{\circ} \mathrm{C}$ in a humidified atmosphere containing $5 \% \mathrm{CO}_{2}$. For CCID formation assays, LECs were stained with cytotracker green purchased from Invitrogen. Three-dimensional co-cultivation of breast cancer spheroids with LEC monolayers: MCF-7 cells (input of 3000 cells for one spheroid) were transferred to $30 \mathrm{ml}$ MEM medium containing $6 \mathrm{ml}$ of a $1.6 \%$ methylcellulose solution $(0.3 \%$ final concentration; cat. no.: M-512, 4000 centipoises; SigmaAldrich). A total of $150 \mu \mathrm{l}$ of this cell suspension (containing 3000 cells) was transferred to each well of a 96-well plate (Cellstar 650185; Greiner Bio-one, Kremsmünster, Austria) to allow spheroid formation within $48 \mathrm{~h}$.

The CCID assay. In this model, the sizes of the cell-free areas (CCIDs) are measured that are formed in the endothelial monolayer directly underneath 12(S)-HETE-secreting tumour spheroids, which is a mechanistic cause for this phenomenon (Madlener et al, 2010; Kerjaschki et al, 2011; Vonach et al, 2011; Viola et al, 2012). MCF-7 spheroids were washed in PBS and transferred to cytotracker-stained LEC monolayers that were seeded into 24-well plates (Costar 3524; Sigma-Aldrich) in $2 \mathrm{ml}$ EGM2 MV medium. After $4 \mathrm{~h}$ of incubation, the CCID areas in the LEC monolayers underneath the MCF-7 spheroids were photographed using an Axiovert (Zeiss, Jena, Germany) fluorescence microscope to visualise cytotracker (green)-stained LECs underneath the spheroids. The CCID areas were calculated with the Axiovision Re.4.5 software (Zeiss). DMSO-treated co-cultures served as negative control. For each condition, the CCID size of 12 or more spheroids (unless otherwise specified) was measured. During the experiments, which were mostly short term, we did not observe toxic effects of the used drugs (monitored by HOPI staining; Grusch et al, 2002).

Sodium dodecyl sulphate (SDS) gel electrophoresis and western blotting. LECs were grown in petri dishes (6-cm diameter) to $80 \%$ confluence and treated with $1 \mu \mathrm{m}$ 12(S)-HETE and/or the indicated drug concentrations. Then, cells were washed twice with cold PBS and lysed in a buffer containing $150 \mathrm{~mm} \mathrm{NaCl}, 50 \mathrm{~mm}$ Tris $\mathrm{pH}$ 8.0, $1 \%$ Triton-X-100, $1 \mathrm{~mm}$ phenylmethylsulfonyl fluoride and $1 \mathrm{~mm}$ protease inhibitor cocktail (Sigma, Schnelldorf, Germany). The lysates were centrifuged at 12000 r.p.m. for $20 \mathrm{~min}$ at $4{ }^{\circ} \mathrm{C}$, and the supernatants were transferred to $1.5-\mathrm{ml}$ tubes and stored at $-20{ }^{\circ} \mathrm{C}$ until further analysis. Equal amounts of protein lysate were mixed with $(\times 2)$ SDS sample buffer and loaded onto a $10 \%$ polyacrylamide gel. SDS polyacrylamide gel electrophoresis and western blotting were according to the protocol described by Vonach et al (2011).

NF- $\boldsymbol{\kappa}$ B luciferase assay. $10 \times 10^{6}$ HEK293-NF- $\kappa$ B-Luc cells (Panomics, Fremont, CA, USA) were seeded in $20 \mathrm{ml}$ full growth DMEM medium in a $15-\mathrm{cm}$ dish. Next day, cells were transfected with an expression plasmid for green fluorescence protein (GFP) (pEGFP-N1; Clontech, Mountain View, CA, USA). A total of $30 \mu \mathrm{l}$ Lipofectamin 2000 (Invitrogen) and $7.5 \mu \mathrm{g}$ DNA were mixed in $2 \mathrm{ml}$ transfection medium and incubated for $20 \mathrm{~min}$ at room temperature, followed by adding this mixture to the cells. After 
incubation for $6 \mathrm{~h}$ in humidified atmosphere containing $5 \% \mathrm{CO}_{2}$, $4 \times 10^{4}$ cells per well were seeded in serum- and phenol red-free DMEM in a transparent 96-well plate. On the next day, cells were treated with the indicated drugs and $2.5 \mu \mathrm{M}$ parthenolide as a specific inhibitor of NF- $\kappa \mathrm{B}$ (control). One hour after treatment, cells were stimulated with $2 \mathrm{ng} \mathrm{ml}^{-1}$ human recombinant TNF $\alpha$ for additional $4 \mathrm{~h}$. Luminescence of the firefly luciferase and fluorescence of the GFP were quantified on a GeniusPro plate reader (Tecan, Grödig, Austria). The luciferase signal derived from the NF- $\kappa \mathrm{B}$ reporter was normalised by the GFP-derived fluorescence to account for differences in cell number (Giessrigl et al, 2012).

12(S)-HETE assay. 12(S)-HETE, which is secreted by MCF-7 spheroids, is a trigger factor of directional LEC migration and, thus, CCID formation. Hence, we studied the influence of candidate drugs on 12(S)-HETE synthesis in a MCF-7 clone. A commercially available 12(S)-HETE EIA (enzyme immunoassay) kit was not sensitive enough to detect 12(S)-HETE produced by normal MCF-7 cells. Therefore, ALOX12 cDNA was overexpressed to detect 12(S)-HETE baseline levels and its alterations after drug treatment.

Cell culture. ALOX15 of MCF-7 cells were knocked down by lentiviral-packaged shRNA, and 12(S)-HETE synthesis was reconstituted by stable transfection of ALOX12 cDNA as described (Kerjaschki et al, 2011), resulting in MCF-7 ${ }^{\text {ALOX12 }}$ cells. MCF$7^{\text {ALOX12 }}$ cells were cultivated in MEM medium (Gibco no. 10370047, Karlsruhe, Germany) supplemented with 10\% FCS, $1 \%$ GlutaMAX-I (Gibco no. 35050-038), 1\% PS (Gibco no. 15140148), $1 \mathrm{mg} \mathrm{ml}^{-1} \mathrm{G} 148$-sulphate (PAA, no. P25-011), $150 \mu \mathrm{g} \mathrm{ml}^{-1}$ hygromycin B (Sigma-Aldrich, no. H3274) and $1 \mu \mathrm{g} \mathrm{ml}^{-1}$ puromycin. The cells were grown at $37^{\circ} \mathrm{C}$ in a humidified atmosphere containing $5 \% \mathrm{CO}_{2}$.

Treatment. MCF- $7^{\mathrm{ALOX} 12}$ cells were seeded in $3.5-\mathrm{cm}$ dishes and grown in $2.5 \mathrm{ml}$ complete MEM medium without selection pressure. The next day, the medium was changed to serum-free medium and cells were kept at $37^{\circ} \mathrm{C}$ for $24 \mathrm{~h}$. Then, cells were treated with $10 \mu \mathrm{M}$ arachidonic acid (no. A3555, Sigma-Aldrich) and simultaneously with different concentrations of the indicated compounds for $4 \mathrm{~h}$ when the supernatants were aspirated, centrifuged at 2000 r.p.m. at $4{ }^{\circ} \mathrm{C}$ for $5 \mathrm{~min}$, collected in cryotubes, flash frozen and stored at $-80^{\circ} \mathrm{C}$ until analysis.

12(S)-HETE extraction. Medium samples of MCF-7 $7^{\mathrm{ALOX} 12}$ cells were slowly thawed at room temperature and centrifuged at 3000 r.p.m. for $2 \mathrm{~min}$. Extraction cartridges (Oasis HLB 1cc; Waters, Milford, MA, USA) were equilibrated with $2 \times 1 \mathrm{ml}$ methanol (highest purity) and $2 \times 1 \mathrm{ml}$ distilled $\mathrm{H}_{2} \mathrm{O}$, and $1.25 \mathrm{ml}$ of medium samples were passed through the cartridges. Afterwards, the cartridges were washed with $3 \times 1 \mathrm{ml}$ distilled $\mathrm{H}_{2} \mathrm{O}$, and 12(S)-HETE was eluted with $500 \mu \mathrm{l}$ methanol. The methanolic solution was flash frozen and stored at $-80^{\circ} \mathrm{C}$ until further analysis.

Analysis by 12(S)-HETE EIA. The 12(S)-HETE EIA (enzyme immunoassay) kit (no. ADI-900-050) was purchased from Enzo Life Sciences (Lausen, Switzerland), and the samples were prepared and the assay was performed according to the instructions of the manufacturer. In detail, the methanolic solution was evaporated with a speed-vac concentrator, $250 \mu$ lof assay buffer were added to the dried samples and a 1:54 dilution was prepared. The standards (a solution of $500 \mathrm{ng} \mathrm{ml}^{-1}$ 12(S)-HETE, no. 80-0607) for the 12(S)-HETE standard curve were prepared according to the instruction manual. Then, $100 \mu \mathrm{l}$ of the samples and standards were added to a 96-well plate coated with goat anti-rabbit IgG antibody (no. 80-0060). Furthermore, $50 \mu \mathrm{l}$ of 12(S)-HETE conjugate (no. 80-0610; blue solution) and $50 \mu \mathrm{l}$ of rabbit polyclonal antibody (no. 80-0611; yellow solution) were added into the appropriate wells. Afterwards, the plate was incubated at room temperature for $2 \mathrm{~h}$ on a shaker (226 r.p.m.). Then, wells were emptied and washed $3 \times$ with $400 \mu \mathrm{l}$ wash buffer $(1: 20$ dilution of wash buffer concentrate, no. 80-1286), and after the final wash, the plate was tapped on a flint-free paper towel to completely remove the wash buffer. A total of $200 \mu$ l of the pNPP substrate (no. 800075) solution was pipetted into each well and incubated for $3 \mathrm{~h}$ at $37^{\circ} \mathrm{C}$ in a humidified atmosphere containing $5 \% \mathrm{CO}_{2}$. Then, $50 \mu \mathrm{l}$ of the stop solution (no. 80-0247) was added into each well, and absorbance was measured with a Wallac 1420 Victor 2 multilabel plate reader (Perkin Elmer Life and Analytical Sciences, Waltham, MA, USA).

Statistical analysis. For statistical analyses, Excel 2003 software and Prism 5 software package (GraphPad, San Diego, CA, USA) were used. The values were expressed as mean \pm s.e.m., and the Student's $t$-test was used to compare differences between controls and individual samples, whereas analyses of variance (ANOVAs; one-way ANOVA together with Dunnett's post test) was used to analyse treatment groups. Statistical significance level was set at $P<0.05$. The calculations of drug-combination effects were performed using the 'Calcusyn' software (Biosoft, Ferguson, MO, USA) designed by Chou and Talalay $(1981,1984)$. This method analyses the interaction among drugs in a given combination and calculates a predictive value at which the effect of a drug combination is additive or above it is synergistic, or below it is antagonistic.

\section{RESULTS}

Acetohexamide, isoxsuprine, nifedipin and proadifen inhibit CCID formation. The screening of 225 FDA-approved drugs and four natural products (Figure 1A-J) showed that acetohexamide, nifedipin, proadifen and isoxsuprine inhibited CCID formation dose dependently (5-60 $\mu \mathrm{m}$; Figure $2 \mathrm{~A}-\mathrm{D})$. The strongest inhibitory effect was observed with isoxsuprine followed by proadifen $>$ nifedipin $>$ acetohexamide.

Acetohexamide and isoxsuprine reduce the 12(S)-HETE level. 12(S)-HETE, which is secreted by MCF-7 spheroids, is a major trigger factor of CCID formation in LEC monolayers. 12(S)HETE is the product of ALOX12/15. Therefore, we analysed whether acetohexamide, isoxsuprine, nifedipin and proadifen inhibited 12(S)-HETE synthesis in an ALOX12-expressing MCF7 clone (MCF-7 ${ }^{\text {ALOX12 }}$ cells) using an adapted EIA assay, which measures the 12(S)-HETE levels in cell-culture supernatants. Acetohexamide and isoxsuprine inhibited 12(S)-HETE synthesis, whereas nifedipin did not alter 12(S)-HETE levels significantly, and proadifen even induced the 12 (S)-HETE level in MCF-7 $7^{\text {ALOX12 }}$ cells (Figure 3).

Proadifen and nifedipin inhibit activation of NF- $\kappa$ B. Recent studies showed that the activity of $\mathrm{NF}-\kappa \mathrm{B}$ (in addition to the activity of ALOX12/15 of MCF-7 cells) contributes to CCID formation (Vonach et al, 2011; Viola et al, 2012). Therefore, we assesed the effect of acetohexamide, isoxsuprine, nifedipin and proadifen on NF- $\kappa \mathrm{B}$ activity using a luciferase reporter fused to a $\mathrm{NF}-\kappa \mathrm{B}$-responsive promoter. Nifedipin and proadifen inhibited the activation of the NF- $\kappa$ B reporter construct, whereas acetohexamide and isoxsuprine did not alter the read out (Figure 4).

Inhibition of mobility markers. The formation of CCIDs, which are triggered by MCF-7 spheroids, requires LEC mobility and, therefore, the induction of proteins facilitating cell migration. Hence, the expression of the mobility proteins MYPT, MLC2 and 

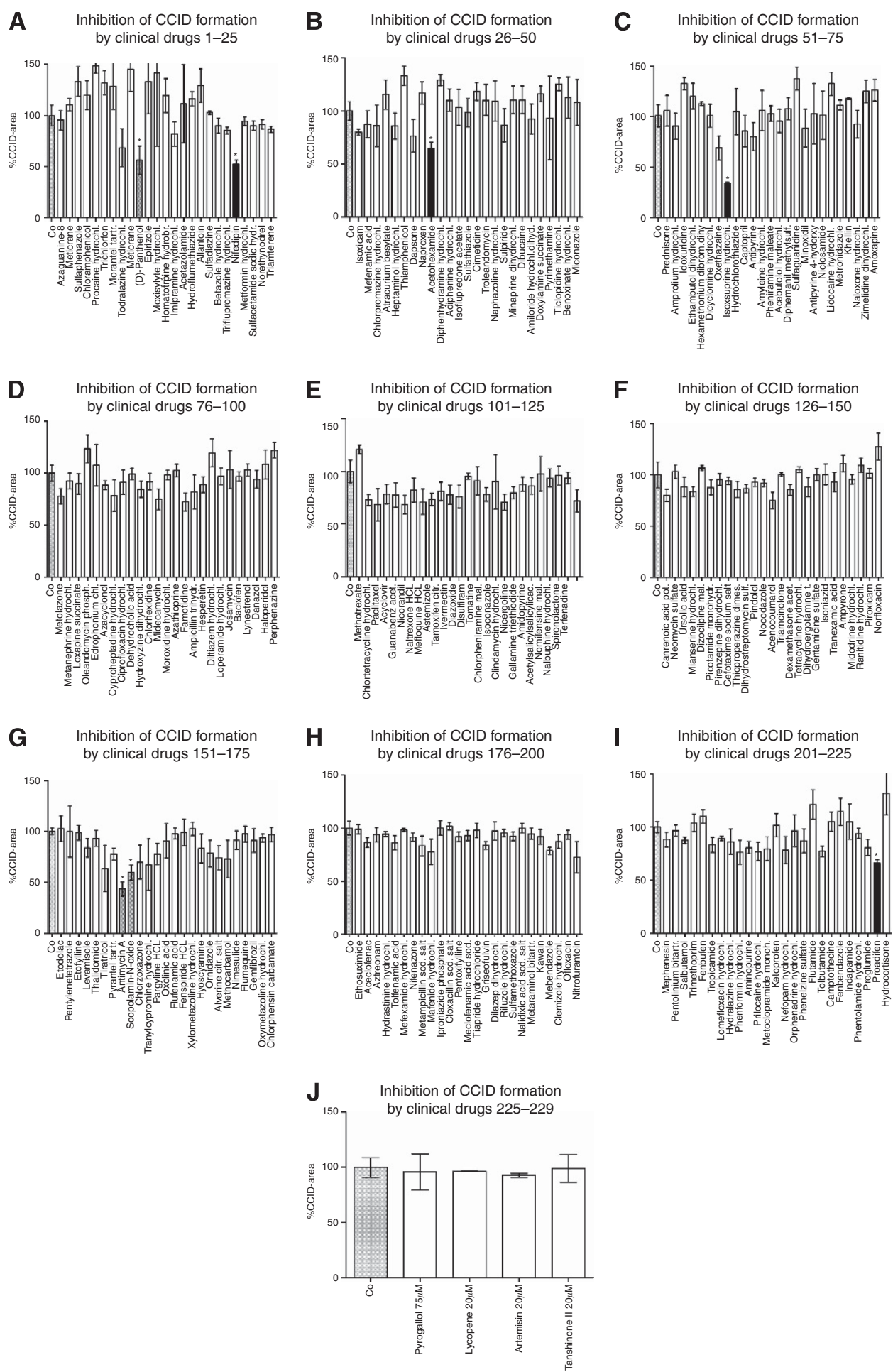

Figure 1. (A-J) Effect of FDA-approved drugs (A-I) and natural compounds (J) on CCID formation. MCF-7 spheroids were placed on LEC monolayers and co-cultivated for $4 \mathrm{~h}$ either with medium alone and solvent (DMSO; Co) or with $40 \mu \mathrm{m}$ of the indicated drugs, and then the areas of $C C I D s$ were measured. Asterisks indicate significance ( $t$-test compared with untreated controls; $P<0.05)$ and error bars indicate mean $\pm s . e . m$. Black columns indicate the drugs whose activities were confirmed in subsequent dose response experiments (see Figure 2A-D). Grey columns indicate those drugs that turned out to be false positives.

paxillin was studied and also that of Erk1/2 because it was shown to mediate migratory signals (Webb et al, 2004). We simplified the three-dimensional co-culture cell model and replaced MCF-7 spheroids (as source of 12(S)-HETE stimulation) by direct $12(\mathrm{~S})$ HETE treatment, which allowed to perform western blot analyses. Interestingly, 12(S)-HETE transiently downregulated Erk1/2 phosphorylation (Vonach et al, 2011; Viola et al, 2012). Acetohexamide, isoxsuprine, nifedipin and proadifen inhibited one or more mobility markers (MLC2, MYPT and paxillin) in LECs (Figure 5A-D), thereby providing a molecular explanation for attenuated LEC migration. Proadifen downregulated paxillin expression and reversed 12(S)-HETE-mediated Erk1/2 de-phosphorylation. Acetohexamide strongly inhibited 12(S)-HETEinduced phosphorylation of MLC2, and also MYPT 

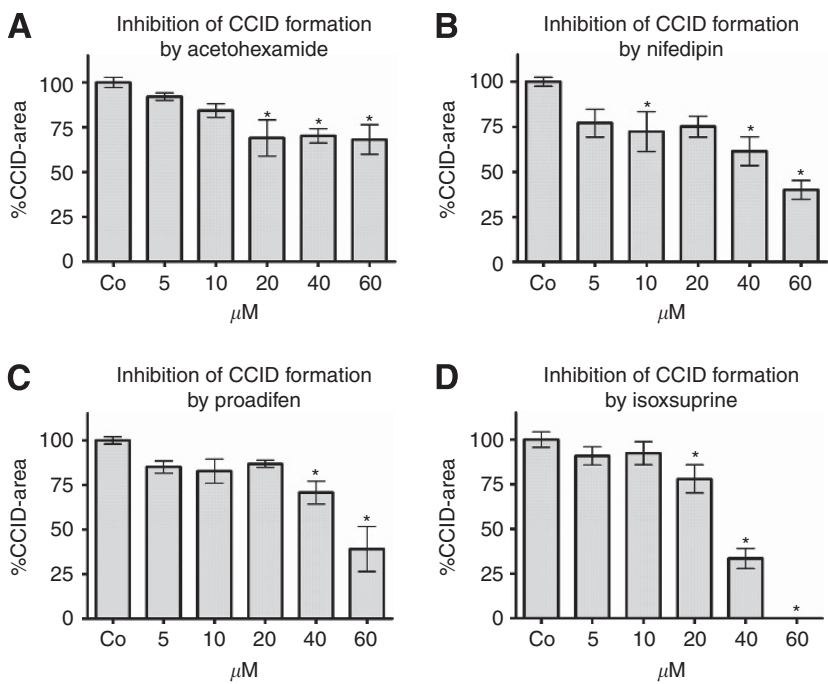

Figure 2. (A-D) Inhibitory effect of acetohexamide, nifedipin, proadifen and isoxsuprine on CCID formation. MCF-7 spheroids were placed on LEC monolayers and co-cultivated for $4 \mathrm{~h}$ either with medium alone and solvent (DMSO; Co) or with increasing concentrations of acetohexamide, nifedipin, proadifen and isoxsuprine, and then the areas of CCIDs were measured. Per experimental condition, the areas underneath of at least 12 spheroids were analysed. Asterisks indicate significance (one-way ANOVA and Dunnett's post test compared with untreated control; $P<0.05)$ and error bars indicate mean \pm s.e.m.

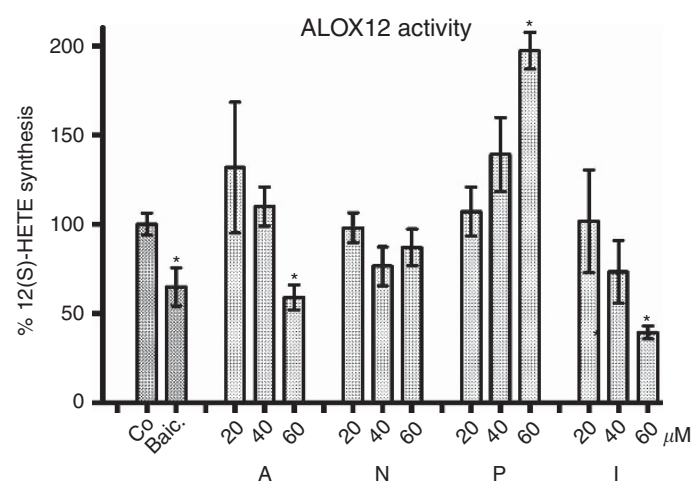

Figure 3. Effect of acetohexamide, nifedipin, proadifen and isoxsuprine on ALOX12 activity. MCF-7 ${ }^{\text {ALOX12 }}$ cells were seeded in $3.5-\mathrm{cm}$ dishes and grown to $70 \%$ confluence and treated with $10 \mu \mathrm{m}$ arachidonic acid together with the indicated concentrations of acetohexamide $(\mathrm{A})$, nifedipin $(\mathrm{N})$, proadifen $(\mathrm{P})$ and isoxsuprine $(\mathrm{I})$ and $50 \mu \mathrm{m}$ baicalein (Baic.) for $4 \mathrm{~h}$. DMSO was used as control (Co). Then, 12(S)-HETE was determined by EIA. Experiments were performed in triplicate. Asterisks indicate significance (one-way ANOVA and Dunnett's post test compared with untreated control; $P<0.05)$ and error bars indicate mean \pm s.e.m.

phosphorylation was weakly inhibited. Nifedipin strongly suppressed the phosphorylation of MYPT, whereas phosphorylation of MLC2 became induced. Isoxsuprine was the only drug inhibiting the induction of all three mobility markers. Therefore, all four CCID-inhibitory drugs affected the expression/activation of one or more mobility proteins.

Combinatorial drug treatment further reduces CCID areas. The drug concentrations that substantially inhibited CCID formation were rather high and physiologically not relevant $(60 \mu \mathrm{M})$.

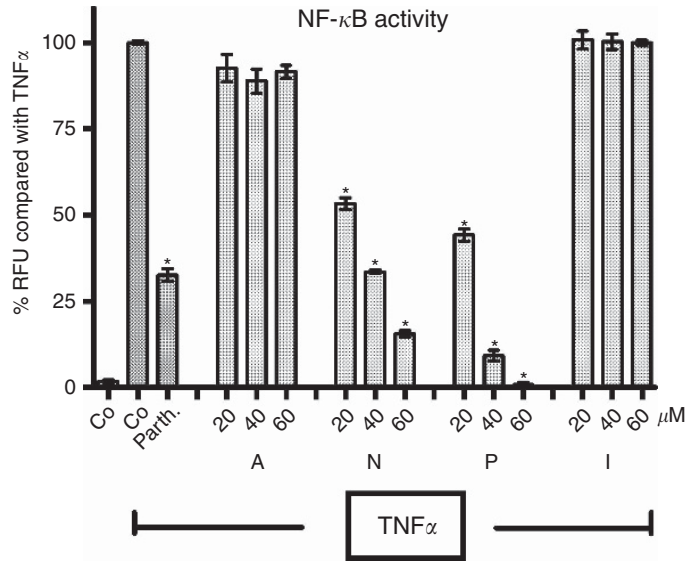

Figure 4. HEK293-NF $\kappa$ B-Luc cells transfected with the cDNA of GFP were treated with the indicated drug concentrations of acetohexamide $(\mathrm{A})$, nifedipin $(\mathrm{N})$, proadifen $(\mathrm{P})$, isoxsuprine (I) or $2.5 \mu \mathrm{M}$ parthenolide (Parth.) as a specific inhibitor of $\mathrm{NF}-\kappa \mathrm{B}$, or solvent (Co; DMSO) control. After stimulation with $T N F \alpha\left(2 \mathrm{ng} \mathrm{ml}^{-1}\right)$ for $4 \mathrm{~h}$, luminescence of the firefly luciferase and fluorescence of GFP were quantified, and the luciferase signal was normalised by the GFP-derived fluorescence. Experiments were performed in triplicate. Asterisks indicate significance (one-way ANOVA and Dunnett's post test compared with $\mathrm{TNF} \alpha$ control; $P<0.05)$ and error bars indicate mean \pm s.d.
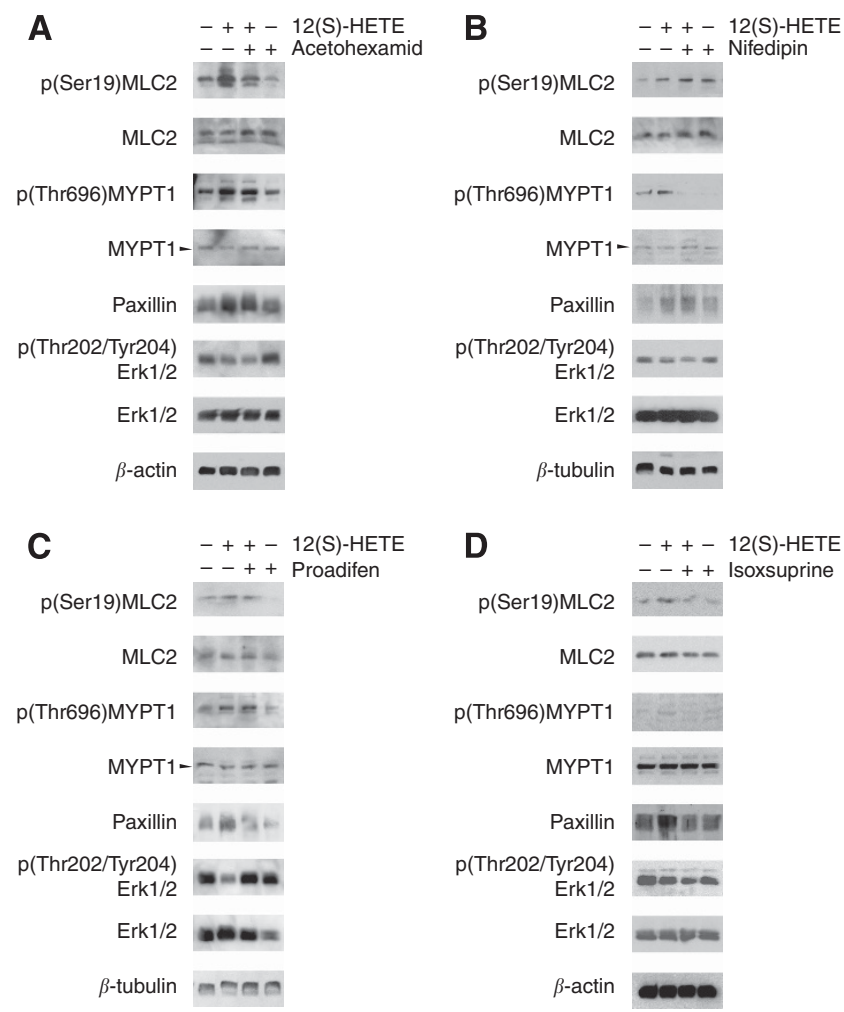

Figure 5. (A-D) Analysis of protein expression. LECs were pretreated with $60 \mu \mathrm{m}$ acetohexamide (A), nifedipin (B), proadifen (C), isoxsuprine (D) and solvent (negative control; - ,-) for $20 \mathrm{~min}$ and/or stimulated afterwards with $1 \mu \mathrm{m} 12(\mathrm{~S})$-HETE for $60 \mathrm{~min}$. Then, cells were harvested and protein lysates were analysed by western blotting. $\beta$-actin and $\beta$-tubulin analyses served as loading control.

Therefore, we performed combination experiments aiming towards the reduction of the individual drug concentrations. Together with the other three drugs (acetohexamide, nifedipin and proadifen, 
$20 \mu \mathrm{M}$ each), the effect of $20 \mu \mathrm{m}$ isoxsuprine was significantly improved (Table 1). Two of the drug combinations (isoxsuprine together with nifedipin, or proadifen) synergised in inhibiting CCID formation when compared with single-drug treatment, whereas isoxsuprine in combination with acetohexamide was additive (Figure 6A, Table 2). This was in agreement with the observation that isoxsuprine was the most potent CCID inhibitor and with its property to downregulate all three of the analysed LEC mobility markers.

The weakest drug and also a weak cooperation partner was acetohexamide, which inhibited ALOX12 less efficiently than isoxsuprine. Acetohexamide, which downregulated two mobility markers (MYPT and MLC2), synergised just with nifedipin. Nifedipin synergised with two drugs (isoxsuprine and acetohexamide) and suppressed MYPT phosphorylation, whereas that of MLC2 became even induced. Therefore, the inhibition of MYPT activity may have been crucial for the synergistic and additive inhibition of CCID formation (by nifidipin and acetohexamide, nifidipin and isoxsuprine and acetohexamide and isoxsuprine, respectively), whereas MLC2 may have been negligible. From this perspective, the reason why nifidipin and proadifen was not efficient remains obscure. From another perspective, both proadifen and nifedipin inhibited NF- $\kappa$ B but not ALOX12, which could explain why this combination did not further reduce CCID formation (Figure 6B). Proadifen synergised only with isoxsuprine, and this combination inhibited CCID formation most effectively and was only topped by the combination of all four drugs. Furthermore, also nifedipin \& isoxsuprine, and nifedipin \& acetohexamide synergistically reduced CCID formation. In these combinations, the first drug inhibited NF- $\kappa \mathrm{B}$ and the other one inhibited ALOX12 (respectively). The antagonistic effect (determined by Calcusyn software) of proadifen and acetohexamide cotreatment may have been due to the opposing effects of the two drugs on 12(S)-HETE synthesis. Interestingly, the combination treatment with the two drugs that inhibit ALOX12 (acetohexamide and isoxsuprine) inhibited CCID formation additively. In contrast, the combination treatment with the two NF- $\kappa \mathrm{B}$-inhibitory drugs (proadifen and nifedipin) was antagonistic, which may have been because of the 12(S)-HETE-increasing property of proadifen.

\section{DISCUSSION}

Metastasising ductal breast cancer emboli secrete 12(S)-HETE, which causes the subsequent retraction of beneath LECs, thereby forming entry ports for the tumour bulk into the lymphatic vasculature (Kerjaschki et al, 2011). This way the tumour passes on from lymph node to lymph node. Normally, 12(S)-HETE is produced by ALOX12 and ALOX15-1 (Funk, 1996) of platelets,

\begin{tabular}{l} 
Table 1. Significance of improvement of CCID inhibition by treatment \\
with drug combinations \\
\hline
\end{tabular}

Abbreviations: $\mathrm{A}=$ acetohexamide; $\mathrm{I}=$ isoxsuprine; $\mathrm{N}=$ nifedipin; $\mathrm{P}=$ proadifen. The effect of combination treatment versus single-drug treatment on CCID inhibition was analysed by t-test, and the $P$-values are shown $(P<0.05$ - significant). leukocytes, smooth muscle, epithelial, neuronal and fibroblast cells (Spector et al, 1988), induces retraction of microvascular endothelial cells (MECs) and increases tumour cell adhesion to exposed ECM (Tang et al, 1993; Honn et al, 1994). Also, MCF-7 breast cancer cells secrete 12(S)-HETE (Uchide et al, 2007), inducing a mobile phenotype and CCIDs in adjacent LECs and causing lymph node metastasis in scid mice (Madlener et al, 2010; Kerjaschki et al, 2011; Vonach et al, 2011). Hence, CCID formation in the three-dimensional co-culture model consisting of MCF-7 spheroids and LEC monolayers faithfully resembles the in vivo situation. Previous experiments could associate phosphorylated MYPT1 with LEC migration (Kerjaschki et al, 2011; Vonach et al, 2011). MYPT1 is the regulatory/targeting subunit of the myosin phosphatase, which regulates the interaction of actin and myosin in response to signalling through the GTPase Rho (Feng et al, 1999). Here we demonstrate an increase of phosphorylation and hence activation of both proteins - MYPT1 and MLC2 - in 12(S)HETE-treated LECs. Also, paxillin expression was induced by 12(S)-HETE. Paxillin is essential for labile adhesions facilitating rapid cell migration (Huang et al, 2003; Deakin and Turner, 2008) and cell polarity (Digman et al, 2008) as prerequisites for directional LEC movement (West et al, 2001; Jianxin et al, 2009) and, hence, CCID formation. Paxillin expression is indicative for cell plasticity and a marker of an undifferentiated phenotype and hallmark protein of EMT (Lu et al, 2006; Zeisberg and Neilson, 2009; Paulitschke et al, 2010; van Zijl et al, 2011). Endothelial paxillin facilitates the transmigration of neutrophils through the endothelial barrier and, thus, influences the behaviour of other cell types that are in direct contact with endothelial cells (Parsons et al, 2012). Because 12(S)-HETE induced MYPT, MLC2 and paxillin in LECs, these proteins can serve as biochemical mobility markers in the CCID-forming process and, moreover, provide a mechanistic explanation for the inhibitory effects of the candidate drugs.

Acetohexamide, isoxsuprine, nifedipin and proadifen not only exhibited an impact on LEC motility markers but also targeted distinct cellular mechanisms relevant for CCID formation, such as the activities of ALOX12 and NF- $\kappa$ B. The chemical structures of these drugs are not related to each other and they are used against distinct diseases. Isoxsuprine is used as a vasodilator in humans and equines (Knoll et al, 1996; Erkert and Macallister, 2002), is applied in humans for the treatment of premature labour (Giorgino and Egan, 2010), and in the horse, isoxsuprine is used to treat hoof-related problems and to increase circulation within the hoof (Erkert and Macallister, 2002). Isoxsuprine is a betaadrenergic agonist that causes direct relaxation of uterine (Kato et al, 1971) and vascular smooth muscle (Belloli et al, 2000). In smooth muscle, MLC kinase phosphorylates MLC2 (Ikebe and Hartshorne, 1985), and this is correlated with myosin ATPase activity and smooth muscle contraction (Tan et al, 1992). 12(S)HETE induces the phosphorylation of MLC in melanoma cells (Rice et al, 1998), and also in MECs, 12(S)-HETE-induced mobility is mediated through enhanced phosphorylation (activation) of proteins co-migrating with MLC (Tang et al, 1993). Conversely, de-phosphorylation of MLC would suspend cell contraction and movement. Therefore, the smooth muscle-relaxing effect of isoxsuprine could be because of the as yet unreported property to inhibit the phosphorylation and activity of MLC2, which itself correlates directly with LEC mobility (Vonach et al, 2011). Furthermore, isoxsuprine exhibited a suppressive effect on 12(S)HETE levels in MCF-7 ${ }^{\text {ALOX12 }}$ cells, which was not observed so far. Isoxsuprine strongly affected LEC migration in the co-culture model when applied in combination with the NF- $\kappa \mathrm{B}$-inhibitory drugs, because NF- $\kappa \mathrm{B}$ is involved in a separate CCID-promoting mechanism. It is widely accepted that NF- $\kappa \mathrm{B}$ is associated with cancer development (Folmer et al, 2009), promoting oncogenesis through the transcriptional activation of genes associated with 


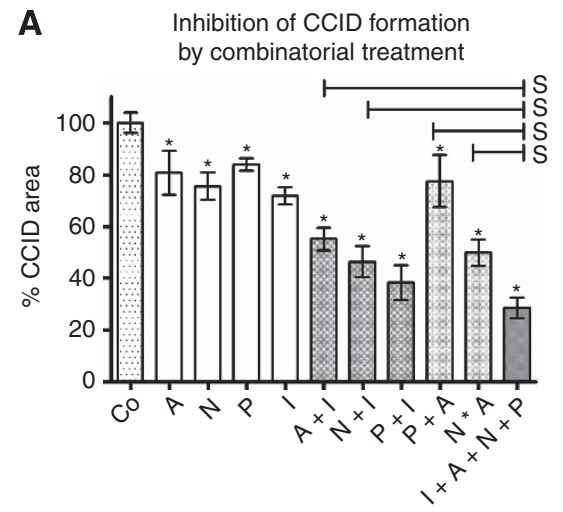

Inhibition of CCID formation
by combinatorial treatment

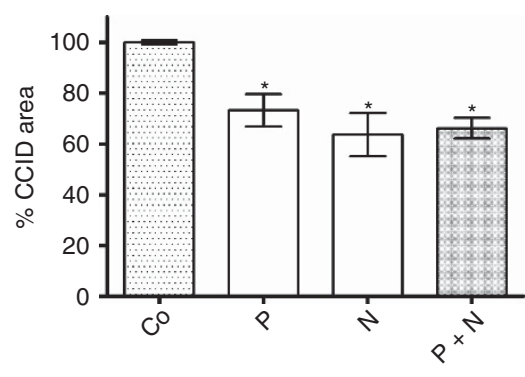

Each $40 \mu \mathrm{M}$

Each $20 \mu \mathrm{M}$

Figure 6. (A, B) Analysis of drug combinations on CCID formation. MCF-7 spheroids were placed on LEC monolayers and co-cultivated for $4 \mathrm{~h}$ either with solvent (DMSO; Co) or (A) with the indicated single drugs $(20 \mu \mathrm{M})$ or drug combinations: acetohexamide (A), nifedipin (N), proadifen (P), isoxsuprine (I) (20 $\mu \mathrm{m}$ each; solvent was kept constant). (B) The combination of P together with $\mathrm{N}(40 \mu \mathrm{m})$ had no additional effect. Per experimental condition, the areas underneath of at least 12 spheroids were analysed. Error bars indicate mean \pm s.e.m., asterisks significance (t-test) between control and treatments and ' $s$ ' between double treatments and quadruple treatments $(s ; P<0.05)$. The significant differences between single treatments and double (and quadruple) treatments are shown in Table 1.

\begin{tabular}{|c|c|c|c|}
\hline Compound(s) & $\begin{array}{c}\text { Concentration } \\
(\mu \mathrm{M})\end{array}$ & $\begin{array}{l}\text { CCID formation ( } \% \\
\text { of control) } \pm \text { s.d. }\end{array}$ & $\begin{array}{c}\text { Predicted } \\
\text { value }^{\mathrm{a}}\end{array}$ \\
\hline A & 20 & $80.73 ; \pm 29.63$ & \\
\hline $\mathrm{N}$ & 20 & $75.48 ; \pm 18.42$ & \\
\hline$P$ & 20 & $83.87 ; \pm 10.85$ & \\
\hline I & 20 & $71.87 ; \pm 11.57$ & \\
\hline$A$ and $I$ & $20 / 20$ & $55.12 ; \pm 18.33^{a}$ & 58.02 \\
\hline $\mathrm{N}$ and I & $20 / 20$ & $46.43 ; \pm 21.89^{b}$ & 54.25 \\
\hline$P$ and $I$ & $20 / 20$ & $38.35 ; \pm 27.80^{b}$ & 60.28 \\
\hline $\mathrm{P}$ and $\mathrm{A}$ & $20 / 20$ & $77.53 ; \pm 34.95^{c}$ & 67.71 \\
\hline $\mathrm{N}$ and $\mathrm{A}$ & $20 / 20$ & $49.93 ; \pm 17.43^{b}$ & 60.93 \\
\hline $\mathrm{I}, \mathrm{A}, \mathrm{N}$ and $\mathrm{P}$ & $20 / 20 / 20 / 20$ & $28.59 ; \pm 13.91^{b}$ & 36.73 \\
\hline$N$ & 40 & $63.67 ; \pm 29.16$ & \\
\hline$P$ & 40 & $73.20 ; \pm 21.77$ & \\
\hline $\mathrm{N}$ and $\mathrm{P}$ & $40 / 40$ & $66.15 ; \pm 14.11^{c}$ & 46.60 \\
\hline \multicolumn{4}{|c|}{ 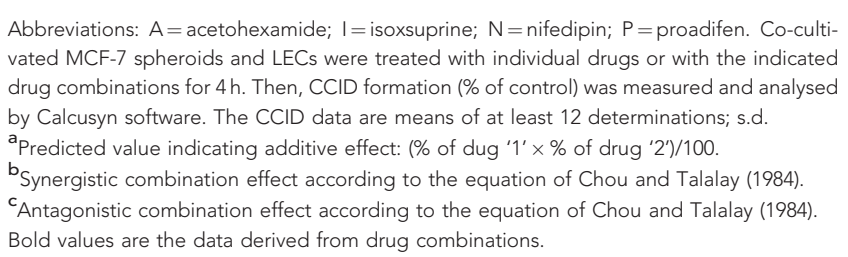 } \\
\hline
\end{tabular}

cell proliferation, angiogenesis and metastasis (Orlowski and Baldwin, 2002).

Nifedipin interacts with the binding site of the receptors associated with calcium channels (Swanson and Green, 1986) and inhibits the influx of exogenic calcium in the smooth muscle cells (Wiemer et al, 1992). This causes their relaxation (Kanmura et al, 1983), and therefore, it is administered to patients with coronary heart diseases and hypertonia (Lundy et al, 2009). The smooth muscle-relaxing property of nifedipin is reminiscent to that of isoxsuprine and could be because of the inactivation of the mobility marker MYPT. This would mechanistically link the therapeutic effect of nifedipin to the inhibition of LEC mobility and CCID formation. In addition, nifedipin inhibited NF- $\kappa \mathrm{B}$ (but not ALOX12), and neither this nor its MYPT-inhibitory property have been observed so far.

Proadifen blocks glibenclamide-sensitive $\mathrm{K}+$ channels (Sakuta and Yoneda, 1994), stimulates prostocylin through the inhibition of platelet thromboxane synthesis (Boeynaems et al, 1987) and inhibits neuronal nitric oxide synthase (Metea and Newman, 2006) and hepatic drug metabolism through the inhibition of the cytochrome P-450 (CYP) system (Ueno et al, 1997). The CYP was shown to promote metastases in humans (Jiang et al, 2007). Recently, it was demonstrated that proadifen inhibits CYP also in MCF-7 cells (Seelinger et al, 2012), and hence, CYP activity of MCF-7 cells might contribute to CCID formation of LECs, that is, by disturbing arachidonic acid metabolism for which ALOX is also competing. In fact, proadifen treatment perturbed (increased) the 12 (S)-HETE level in MCF-7 $7^{\text {ALOX12 }}$ cells. However, proadifen inhibited also NF- $\kappa \mathrm{B}$, and paxillin expression in LECs and thus, counteracted intercellular communication and directional LEC migration.

Acetohexamide is used for the treatment of diabetes mellitus type 2 because it has a positive influence on the release of insulin from the active beta cells in the pancreas. Further, it improves the binding between insulin to insulin receptors (Sheldon et al, 1966; Nakamura, 1984; Imamura et al, 1989). We could not link the therapeutic use or known mechanism of acetohexamide to its CCID-inhibitory property. It was the drug with the weakest effect and correlated with the inhibition of ALOX12 and MLC2 phosphorylation.

Summing up, screening of 229 drugs could identify four drugs that inhibited CCID formation and detailed investigations elucidated their potential mechanisms responsible for this inhibitory property. For three drugs, we could, in part, link the mechanism to their therapeutic effects.

Recent reports demonstrate that inhibition of ALOX12/15 is a prime target for the attenuation of lymph node metastasis (Kerjaschki et al, 2011; Vonach et al, 2011), and together with inhibition of NF- $\kappa \mathrm{B}$ attenuates CCID formation additively (Viola et al, 2012). Some drug combinations with different mechanistic profiles exhibited synergistic effects, and this allowed reducing the drug concentrations. This supports the notion that the individual drugs targeted more than just one CCID-forming mechanism. Hence, as a consequence from our preliminary data, these and 
other drug combinations could be considered for adjuvant antimetastatic therapy.

\section{ACKNOWLEDGEMENTS}

We thank Toni Jäger for preparing the figures. Further, a grant of the Fellinger foundation (to GK), grants of the Herzfelder family foundation (to TS, HD and $\mathrm{MG}$ ) and grants by the Austrian Science Fund, FWF, grant numbers P20905-B13 (WM) and NFNS10704 (VMD) and by the European Union, FP7 Health Research, project number HEALTH-F4-2008-202047 (WM) are gratefully acknowledged.

\section{REFERENCES}

Belloli C, Carcano R, Arioli F, Beretta C (2000) Affinity of isoxsuprine for adrenoreceptors in equine digital artery and implications for vasodilatory action. Equine Vet J 32(2): 119-124.

Boeynaems JM, Demolle D, Van Coevorden A (1987) Stimulation of vascular prostacyclin by SKF 525-A (proadifen) and related compounds. Biochem Pharmacol 36(10): 1637-1643.

Chou TC, Talalay P (1984) Quantitative analysis of dose-effect relationships: the combined effects of multiple drugs or enzyme inhibitors. Adv Enzyme Regul 22: 27-55.

Chou TC, Talalay P (1981) Generalized equations for the analysis of inhibitions of Michaelis-Menten and higher-order kinetic systems with two or more mutually exclusive and nonexclusive inhibitors. Eur $J$ Biochem (FEBS) 115: 207-216.

Deakin NO, Turner CE (2008) Paxillin comes of age. J Cell Sci 121(15): 2435-2444.

Digman MA, Brown CM, Horwitz AM, Mantulin WW, Gratton E (2008) Paxillin dynamics measured during adhesion assembly and disasembly by correlation spectroscopy. Biophys J 94(7): 2819-2831.

Erkert RS, Macallister CG (2002) Isoxsuprine hydrochloride in the horse: a review. J Vet Pharmacol Ther 25(2): 81-87.

Feng J, Masaaki I, Ichikawa K, Isaka N, Nishikawa M, Hartshorne DJ, Nakano $\mathrm{T}$ (1999) Inhibitory phosphorylation site for rho-associated kinase on smooth muscle myosin phosphatase. J Cell Biol 274: 37385-37390.

Folmer F, Jaspars M, Solano G, Cristofanon S, Henry E, Tabudravu J, Black K, Green DH, Küpper FC, Aalbersberg W, Feussner K, Dicato M, Diederich M (2009) The inhibition of TNF- $\alpha$ induced NF- $\kappa B$ activation by marine natural products. Biochem Pharmacol 78: 592-606.

Funk CD (1996) The molecular biology of mammalian lipoxygenases and the quest for eicosanoid functions using lipoxygenase-deficient mice. Biochim Biophys Acta 1304(1): 65-84.

Giessrigl B, Yazici G, Teichmann M, Kopf S, Ghassemi S, Atanasov AG, Dirsch VM, Grusch M, Jäger W, Özmen A, Krupitza G (2012) Effects of scrophularia extracts on tumor cell proliferation, death and intravasation through lymphendothelial cell barriers. Int J Oncol 40(6): 2063-2074.

Giorgino FL, Egan CG (2010) Use of isoxsuprine hydrochloride as a tocolytic agent in the treatment of preterm labour: a systematic review of previous literature. Arzneimittelforschung 60(7): 415-420.

Grusch M, Polgar D, Gfatter S, Leuhuber K, Huettenbrenner S, Leisser C, Fuhrmann G, Kassie F, Steinkellner H, Smid K, Peters GJ, Jayaram H, Klepal T, Szekeres T, Knasmüller S, Krupitza G (2002) Maintenance of ATP favours apoptosis over necrosis triggered by benzamide riboside. Cell Death Differ 9: 169-178.

Honn KV, Tang DG, Grossi I, Duniec ZM, Timar J, Renaud C, Leithauser M, Blair I, Johnson CR, Diglio CA, Kimler VA, Taylor JD, Marnett LJ (1994) Tumour cell-derived 12(S)-hydroxyeicosatetraenoic acid induces microvascular endothelial cell retraction. Cancer Res 54: 565-574.

Huang C, Rajfur Z, Borchers C, Schaller MD, Jacobson K (2003) JNK phosphorylates paxillin and regulates cell migration. Nature 424: 219-223.

Ikebe M, Hartshorne DJ (1985) Phosphorylation of smooth muscle myosin at two distinct sites by myosin light chain kinase. J Biol Chem 260(18): 10027-10031.

Imamura Y, Kojima Y, Otagiri M (1989) Influence of streptozocin-induced diabetes on reductive metabolism of acetohexamide in rat liver. J Pharm Pharmacol 41(3): 186-187.
Jiang JG, Ning YG, Chen C, Ma D, Liu ZJ, Yang S, Zhou J, Xiao X, Zhang XA, Edin ML, Card JW, Wang J, Zeldin DC, Wang DW (2007) Cytochrome p450 epoxygenase promotes human cancer metastasis. Cancer Res 67(14): 6665-6674.

Jianxin AY, Deakin NO, Turner CE (2009) Paxillin-kinase-linker tyrosine phosphorylation regulates directional cell migration. Mol Biol Cell 20(22): 4706-4719.

Kanmura Y, Itoh T, Suzuki H, Ito Y, Kuriyama H (1983) Effects of nifedipine on smooth muscle cells of the rabbit mesenteric artery. J Pharmacol Exp Ther 226(1): 238-248.

Kato K, Ishida M, Azuma Y, Nakanishi S (1971) Effect of isoxsuprine $\mathrm{HCl}$ on the mechanism of relaxation of the uterine muscle. Nihon Sanka Fujinka Gakkai Zasshi 23(9): 825-830.

Kerjaschki D, Bago-Horvath Z, Rudas M, Sexl V, Schneckenleithner C, Wolbank S, Bartel G, Krieger S, Kalt R, Hantusch B, Keller T, Nagy-Bojarszky K, Huttary N, Raab I, Lackner K, Krautgasser K, Schachner H, Kaserer K, Rezar S, Madlener S, Vonach C, Davidovits A, Nosaka H, Hämmerle M, Viola K, Dolznig H, Schreiber M, Nader A, Mikulits W, Gnant M, Hirakawa S, Detmar M, Alitalo K, Nijman S, Offner F, Maier TJ, Steinhilber D, Krupitza G (2011) Lipoxygenase mediates invasion of intrametastatic lymphatic vessels and propagates lymph node metastasis of human mammary carcinoma xenografts in mouse. J Clin Invest 121(5): 2000-2012.

Knoll LD, Benson Jr RC, Bilhartz DL, Minich PJ, Furlow WL (1996) A randomized crossover study using yohimbine and isoxsuprine versus pentoxifylline in the management of vasculogenic impotence. J Urol 155(1): 144-146.

Lu H, Murtagh J, Schwartz EL (2006) The microtubule binding drug laulimalide inhibits vascular endothelial growth factor-induced human endothelial cell migration and is synergistic when combined with docetaxel (taxotere). Mol Pharmacol 69(4): 1207-1215.

Lundy A, Lutfi N, Beckey C (2009) Review of nifedipine GITS in the treatment of high risk patients with coronary artery disease and hypertension. Vasc Health Risk Manag 5(1): 429-440.

Madlener S, Saiko P, Vonach C, Viola K, Huttary N, Stark N, Popescu R, Gridling M, Vo NT, Herbacek I, Davidovits A, Giessrigl B, Venkateswarlu S, Geleff S, Jäger W, Grusch M, Kerjaschki D, Mikulits W, Golakoti T, Fritzer-Szekeres M, Szekeres T, Krupitza G (2010) Multifactorial anticancer effects of digalloyl-resveratrol encompass apoptosis, cell-cycle arrest, and inhibition of lymphendothelial gap formation in vitro. Br J Cancer 102(9): 1361-1370.

Metea MR, Newman EA (2006) Glial cells dilate and constrict blood vessels: a mechanism of neurovascular coupling. J Neurosci 26(11): 2862-2870.

Nakamura T (1984) Influences of oral hypoglycemic agents on the beta-cell of the rabbit pancreas. Nihon Ika Daigaku Zasshi 51(3): 332-338.

Orlowski RZ, Baldwin AS (2002) NF-KB as a therapeutic target in cancer. Trends Mol Med 8(8): 385-389.

Parsons SA, Sharma R, Roccamatisi DL, Zhang H, Petri B, Kubes P, Colarusso P, Patel KD (2012) Endothelial paxillin and focal adhesion kinase (FAK) play a critical role in neutrophil transmigration. Eur J Immunol 42(2): 436-446.

Paulitschke V, Schicher N, Szekeres T, Jäger W, Elbling L, Riemer AB, Scheiner O, Trimurtulu G, Venkateswarlu S, Mikula M, Swoboda A, Fiebiger E, Gerner C, Pehamberger H, Kunstfeld R (2010) 3,3',4,4',5,5'Hexahydroxystilbene impairs melanoma progression in a metastatic mouse model. J Invest Derm 130(6): 1668-1679.

Rice RL, Tang DG, Hddadi M, Honn KV, Taylor JD (1998) 12(S)Hydroxyeicosatetraenoic acid increases microfilament content in B16a melanoma cells: a protein kinase-dependent process. Int J Cancer 77: 271-278.

Sakuta H, Yoneda I (1994) Inhibition by SKF 525A and quinacrine of endogenous glibenclamide-sensitive $\mathrm{K}+$ channels in follicle-enclosed Xenopus oocytes. Eur J Pharmacol 252(1): 117-121.

Seelinger M, Popescu R, Giessrigl B, Jarukamjorn K, Unger C, Wallnöfer B, Fritzer-Szekeres M, Szekeres T, Diaz R, Jäger W, Frisch R, Kopp B, Krupitza G (2012) Methanol extract of the ethnopharmaceutical remedy Smilax spinosa exhibits anti-neoplastic activity. Int J Oncol 41(3): 1164-1172.

Sheldon J, Taylor KW, Anderson J (1966) The effects of long-term acetohexamide treatment on pancreatic islet cell function in maturityonset diabetes. Metabolism 15(10): 874-883. 
Spector AA, Gordon JA, Moore SA (1988) Hydroxyeicosatetraenoic acids (HETEs). Prog Lipid Res 27: 271-323.

Swanson TH, Green CL (1986) Nifedipine: more than a calcium channel blocker. Gen Pharmacol 17(3): 255-260.

Tan JL, Ravid S, Spudich JA (1992) Control of nonmuscle myosins by phosphorylation. Annu Rev Biochem 61: 721-759.

Tang DG, Timar J, Grossi IM, Renaud C, Kimler VA, Diglio CA, Taylor JD, Honn KV (1993) The lipoxygenase metabolite, 12(S)-HETE, induces a protein kinase $\mathrm{C}$-dependent cytoskeletal rearrangement and retraction of microvascular endothelial cells. Exp Cell Res 207: 361-375.

Uchide K, Sakon M, Ariyoshi H, Nakamori S, Tokunaga M, Monden M (2007) Cancer cells cause vascular endothelial cell retraction via 12(S)HETE secretion; the possible role of cancer cell derived microparticle. Ann Surg Oncol 14: 862-868.

Ueno S, Suzuki T, Susa N, Furukawa Y, Sugiyama M (1997) Effect of SKF-525A on liver metabolism and hepatotoxicity of tri- and dibutyltin compounds in mice. Arch Toxicol 71(8): 513-518.

van Zijl F, Krupitza G, Mikulits W (2011) Initial steps of metastasis: Cell invasion and endothelial transmigration. Rev Mutat Res 728(1-2): 23-34.

Viola K, Kopf S, Huttary N, Vonach C, Kretschy N, Teichmann M, Giessrigl B, Raab I, Stary S, Krieger S, Keller T, Bauer S, Hantusch B, Szekeres T, de Martin R, Jäger W, Mikulits W, Dolznig H, Krupitza G, Grusch M (2012) Bay11-7082 inhibits the disintegration of the lymphendothelial barrier triggered by MCF-7 breast cancer spheroids; the role of ICAM- 1 and adhesion. Br J Cancer; e-pub ahead of print, 23 October 2012; doi:10.1038/ bjc.2012.485.
Vonach C, Viola K, Giessrigl B, Huttary N, Raab I, Kalt R, Krieger S, Vo NTP, Madlener S, Bauer S, Marian B, Hämmerle M, Kretschy N, Teichmann M, Hantusch B, Stary S, Unger C, Seelinger M, Eger A, Mader R, Jäger W, Schmidt W, Grusch M, Dolznig H, Mikulits W, Krupitza G (2011) NF-кB mediates the12(S)-HETE-induced endothelial to mesenchymal transition of lymphendothelial cells during the intravasation of breast carcinoma cells. Br J Cancer 105(2): 263-271.

Webb DJ, Donais K, Whitmore LA, Thomas SM, Turner CE, Parsons JT, Horwitz AF (2004) FAK-Src signalling through paxillin, ERK and MLCK regulates adhesion disassembly. Nat Cell Biol 6(2): 154-161.

West KA, Zhang H, Brown MC, Nikolopoulos SN, Riedy MC, Horwitz AF, Turner CE (2001) The LD4 motif of paxillin regulates cell spreading and motility through an interaction with paxillin kinase linker (PKL). J Cell Biol 154(1): 161-176.

Wiemer G, Becker RH, Jablonka B, Rosenkranz G, Schölkens BA, Linz W (1992) Effects of converting enzyme inhibitors and the calcium antagonist nifedipine alone and in combination on precontracted isolated rabbit aortic rings. Arzneimittelforschung 42(6): 795-797.

Zeisberg M, Neilson EG (2009) Biomarkers for epithelial-mesenchymal transitions. J Clin Invest 119(6): 1429-1437.

This work is published under the standard license to publish agreement. After 12 months the work will become freely available and the license terms will switch to a Creative Commons AttributionNonCommercial-Share Alike 3.0 Unported License. 